\title{
NEWS AND REVIEWS
}

\section{RETIRES FROM USDA \\ AGRICULTURAL MARKETING SERVICE}

A. D. Edgar retired March 31 from his position as agricultural engineer with the transportation and facilities research division of the USDA Agricultural Marketing Service after almost 35 years of service. A native of Kansas, he was born in Ashland on July 15, 1898, and received his primary and secondary education there and in Wichita. He entered the U. S. Marines in 1917 where he served honorably during World War I. He received a B.S. degree from Kansas State College (now Kansas State University) in 1925 and did graduate work in mechanical engineering at the University of Idaho from 1927 to 1929.

In 1929 he was employed by the Agricultural Extension Service at Michigan Agricultural College (now Michigan State University). In 1931 he was appointed associate agricultural engineer with USDA and was promoted stuccessively to higher grades. In addition to Michigan, he has been stationed in Maine, Nebraska, Colorado, the Red River Valley of Minnesota-North Dakota, Alaska, Washington, D. C., and Costa Rica.

He has demonstrated a superior degree of competence and comprehension in planning conducting, and directing a complex and detailed progran of engineering research on handling, storage, and preparing potatoes for market. He is the recognized authority in the United States on potato storage problems and his help is sought by commercial firms from all corners of the world. He is the author or co-author of about 60 research reports. In 1959 he received a superior performance award from USDA.

$\mathrm{He}$ is a member of The Potato Association of America, the American Society of Agricultural Engineers, the American Society of Heating, Refrigerating, and Air-Conditioning Engineers, and is a registered professional engineer.

-Herbert Findlen

\section{USE OF DINITROS FOR POTATO VINE KILLING CLARIFIED}

The Dow Chemical Company has announced that two of its products - Premerge and Dow General Weed Killer, both dinitro herbicides - can be used for vine killing on table stock potatoes. This use is in line with existing label directions, according to Dow, and their reminder announcement is intended merely to clarify some confusion as to the proper use of these products.

The Pesticide Regulation Division of the United States Department of Agriculture has just completed a review of additional data on table stock potatoes harvested 10 days after a vine-killing spray with either Premerge or Dow General Weed Killer. These data demonstrated to the satisfaction of the United States Department of Agriculture that no residue of the herbicide would result in, or on, the potato tubers when the materials are used according to current label directions. Growers should avoid spraying exposed tubers.

ERRATUM: Change statement on page 103 to read: In harvesting seed potatoes, they should not be put directly into the ice house. 